\title{
Export Platforms and the Industry-Specific FDI-Trade Relationship
}

\author{
Bedassa Tadesse \\ University of Minnesota-Duluth \\ Michael Ryan \\ Western Michigan University
}

\begin{abstract}
This paper examines how the industry-level FDI-export sales relationship is affected by the host nation's status as an "export platform" (EP). Using Japanese FDI and export sales data into 35 host countries during the period 1989-1998 for 7 ISIC 2-digit industries, we find that the FDI-export sales relationship is industry-specific and sensitive to the host's export platform status. Without accounting for the host's EP status, we find a complementary relationship between FDI and export sales in some industries and a substitution between FDI and export sales in others. However, accounting for the host's EP status changes the FDI-export sales relationship in several industries, implying that the FDI-export sales interaction is sensitive to the EP status of the FDI host countries.
\end{abstract}

- JEL Classifications: F14, F23

- Key words: FDI, Trade, Export Platforms, Manufacturing Exports, Japan

\section{Introduction}

This paper investigates how the industry-level foreign direct investment (FDI)-

\footnotetext{
*Corresponding address: Bedassa Tadesse, Department of Economics, University of Minnesota-Duluth, 412 Library Drive, Dulth, MN55812, USA, Tel: +1-218-726-8365, Fax: +1-218-726-6509, E-mail: btadesse@d.umn.edu. Michael Ryan, Department of Economics, Western Michigan University, 1903 W. Michigan Ave., Kalamazoo, MI-49008, USA, Tel: +1-269-387-5545, Fax: +1-269-387-5637, E-mail: michael.ryan@wmich.edu (C2005-Center for International Economics, Sejong Institution, All Rights Reserved.
} 
trade relationship is influenced by the host nation's status as a location for "export platform" investments. With global production fragmentation increasing, the use of export platforms has become increasingly more important in how multinational enterprises (MNEs) choose to service foreign markets. Defined as foreign affiliates whose output is generally sold in markets other than the parent or host market, export platforms are suggested by Helpman, Melitz, and Yeaple (2004) as a "new motive" for FDI. This now allows for essentially three methods of foreign market servicing: direct exports from the home country, local production in the host (destination) country, and exports from affiliates located outside the home and host markets. While theoretical studies on export platforms focus on the firm's incentive to establish such affiliates (e.g. Ekholm, Forslid, and Markusen (2003)), the "export platform" designation has also been used to describe the host country as well. Owing to a host of geographic, market-based, and/or political factors, many countries have become "export platforms" - countries from which a large percentage of foreign-owned production is exported to third-party markets. For example, Hanson, Mataloni, and Slaughter (2001) show that some 26 per cent of total U.S. foreign affiliate sales during 1993-1994 went to third-party countries. Several countries had totals far exceeding the average, such as Ireland (76 per cent), Belgium (60 per cent), and the Netherlands (59 per cent), suggesting that these countries served as export platforms to the EU market. ${ }^{1}$ For non-U.S. activity, the recent EU-Mexican free trade agreement (as well as the impending MexicoJapan FTA) signals Mexico's status as an export platform to the U.S. market, while increased Japanese FDI into the Central and East European countries designed to service the EU market are additional examples of this FDI trend. ${ }^{2}$

Given the growing trend in export platform investment, we must begin to reconsider how FDI and traditional export trade are related. In the traditional Heckscher-Ohlin (HO) trade theory, FDI and trade are considered as substitutes. ${ }^{3}$

\footnotetext{
${ }^{1}$ This is in sharp contrast to Canada and Mexico, where only 3\% of U.S. export sales went to third-party countries.

${ }^{2}$ Current EU members have also turned an eye toward the CEE countries. For example, "companies that have not yet....invested into the central and eastern European markets should not miss the opportunity in this area," while companies should settle "in countries that can be an export platform towards other areas." [Chambre de Commerce et D'Industrie de Paris, "EU enlargement to the CEECs: an opportunity to be seized by French company?" (2003)]

${ }^{3}$ See Mundell (1957). HO theory views FDI as the export of capital motivated by higher returns arising from tariffs and other trade barriers. Thus, the cross border movement of factors (FDI) substitutes trade in goods. We briefly survey this literature in section 2 .
} 
However, results from empirical observations (e.g., Egger, 2001; Blonigen, 2001; Pfaffermayer, 1996) are at best inconclusive as to the complementaritysubstitutability of FDI and trade. A unifying theme among most of these studies is the implicit assumption that that sales by foreign affiliates are limited to either serving the host market (horizontal, or "market seeking", FDI) or are designed for re-export back to the source country market (vertical, or "resource seeking", FDI). With many countries now serving as export platforms, it is important to add "export platform" to the "vertical or horizontal" dichotomy of FDI motivations. Using aggregated (country-level) data, a recent study by Tadesse and Ryan (2004) indicates that a host's export platform status does have an effect on the FDI-trade link, although they do not focus on the apparent industry-specific nature of the FDI-trade relationship.

In this paper, following Tadesse and Ryan (2004), we account for the host's export platform status and examine its FDI-export sales relationship at the industry level. Our analysis builds on UNCTAD (1996), Safarian (1996), and Dunning (1998) that show how disparities across industries in firm's sequential internationalization process influence the potential FDI-trade links. As such, industry affiliation may determine a foreign affiliate's target market, even if they are located in a country designated as an export platform. Thus, while we maintain the assumption that the FDI-export sales interaction is industry-specific, we hypothesize that the exact nature of this industry-level interaction is not independent of host country characteristics (e.g. its export platform status). We employ Japanese manufacturing FDI data and the corresponding industry level annual export sales of Japan into 35 host countries for seven ISIC 2-digit industries during the period 1989-1998. While the country and time panel nature of our data allows us to focus on host country characteristics as potential FDI and trade determinants, we also account for industry level variations by comparing coefficient estimates across different industries within the manufacturing sector.

Our study makes two important contributions to the empirical literature. First, while analyzing whether FDI is a complement or a substitute to trade at the industry level, we account for previously unaddressed host market characteristicsnamely, the host's export platform status. ${ }^{4}$ Second, by using the ratio of industry-

\footnotetext{
${ }^{4}$ Clearly, a host's economic platform status may be related to its "economic potential" (e.g. Head and Mayer, forthcoming), but they are not necessarily correlated. For example, Luxembourg's economic potential in regard to Europe is much higher than Ireland's, but yet Ireland is a larger export platform than Luxembourg.
} 
specific FDI to the total FDI into each host over 10 years span of time, we account both for the total and relative distribution (allocation) of Japanese FDI over a range of its FDI host nations. Using these ratios as a dependent variable, we are also able to address which host country characteristic(s) play important roles in motivating Japanese investors to allocate different proportion of their FDI in different industries into a given host nation. ${ }^{5}$

We find that the nature of FDI and export sales interaction is industry-specific. We also find that within an industry itself, the FDI-export sales interaction is sensitive to the host's export platform status. Without accounting for the host's export platform status, for example, we find complementary relationships between Japanese FDI and export sales in some industries (e.g. food/beverages and basic metals), while in other industries (e.g. textiles/apparel/leather, wood/furniture, and chemical products) FDI substitutes for export sales. However, when we incorporate the host's export platform status into the model, we observe several changes in the substitute/complementary relationship. That is, in several cases a substitute FDIexport sales relationship turns complementary when the host's export platform status is taken into account. This implies that the exact nature of the FDI and export sales interaction is indeed sensitive to the host's export platform status and thus previous FDI-export sales conclusions are not robust.

The remainder of this paper is organized as follows. Section 2 provides a review of the relevant literature, while a description of the pattern of industry specific Japanese FDI follows in section 3. Section 4 discusses the analytical framework, explanatory variables, and the empirical model. Section 5 presents the estimation results, with concluding remarks provided in section 6 .

\section{Literature Review}

Observations from both theoretical and empirical research reveal that several factors underlie the decision of firms to serve foreign markets. Included among these factors are transportation costs, trade barriers, plant-level fixed costs, scale economies, and factor endowment differences between the hosts and the source countries. The earlier notion on the relationship between FDI and trade is that they are substitutes when affiliates are horizontally organized (market-seeking), and complements when affiliates are vertically organized (resource-seeking) investment

${ }^{5}$ See the appendix for a description of how the dependant variable is computed. 
entities. ${ }^{6}$ The theoretical analysis, for example, by Markusen (1995) indicates that industries that face high trade costs and low plant level economies prefer FDI to exports when servicing their foreign consumers. For these industries, direct investment and exports are thus substitutes. Recent empirical industry-level studies by Gopinath et al. (1999), and Yilamz (2001) support this conclusion.

On the other hand, countries, industries and firms that invest extensively in foreign economies are also the sources of large volumes of exports to the same destination (Head and Ries, 2001). Thus, there appears to be a complementary relationship between FDI and trade. Results from empirical studies by Pfaffermayer (1996) (for Austrian FDI and trade), Hejazi and Safarian (2001) and Marchant, et al. (2002) for the U.S., and Stone and Jeon (2000) for Asian countries support this view.

Apart from the differences in the conclusions about the relationships between FDI and trade, there is a stark difference in the methodological approaches followed by many of these studies. Thus, some of the differences in the conclusions from the empirical literature might be attributed to the variation in the approaches followed. In addition, these studies also fail to address the effect of the host countries' export platform status on the amount of inward FDI, affiliates' export sales, and thereby the FDI-export sales relationship. It is imperative that the export platform status of the host country is taken into account when evaluating the FDI-export sales interaction, because in export platform investment the location choice decision is dictated by cost considerations (a key characteristic of vertical investment) while the target ( $3^{\text {rd }}$-party) market is often a large, high-income country (as in horizontal investment) to which the host country can serve as a gateway. That is, export platform investments have the element of both horizontal (market seeking) and vertical (resource-seeking) FDI and thus it is hard to fit into either of the above classification (Ekholm, et.al., 2003). Therefore, the FDI-trade relationship between the source and host countries may not be as straightforward as once thought and, perhaps for this reason, it is not surprising to see that empirical studies are quite inconclusive as to whether FDI substitutes or complements export sales. $^{7}$

\footnotetext{
${ }^{6}$ See, for instance, Brainard (1997), Markusen (2002), and Markusen and Maskus (2001, 2002).

${ }^{7}$ This fact is well summarized in the geographical production fragmentation literature. See Jones (2000) for an excellent summary of this topic.
} 


\section{Descriptive Characteristics of Industries in the study}

Descriptive statistics of the industry specific Japanese outward FDI and export sales into the 35 host countries in our sample are presented in Table $1 .^{8}$ While data on both manufacturing and non-manufacturing Japanese FDI into these countries are available, we limit our analysis to FDI in the manufacturing sector because industry-specific export sales in non-manufacturing sectors are not fully available for all countries and the time periods that we cover in this study. We follow the International Standard Industry Classification (ISIC) codes and segregate the manufacturing sector into seven industry groups. A list of the seven industry groups and the descriptive statistics of the corresponding industry specific FDI and trade data are presented in Table 1.

The data in the table indicate that during the reference period (1989-1998), Japanese MNEs established some 12,000 new foreign manufacturing affiliates (totaling some $¥ 16$ billion investment). While the total affiliate counts in the seven industries account for about 85 per cent of the total Japanese manufacturing affiliate establishments, the $¥ 16$ billion investment into the affiliates account for nearly 90 per cent of the total Japanese outward manufacturing FDI during the reference period.

Table 1. Summary of Japanese Manufacturing Investment by ISIC (1989-1998)

\begin{tabular}{|c|c|c|c|c|c|}
\hline \multicolumn{2}{|c|}{$\begin{array}{l}\text { ISIC } \\
\text { Code }\end{array}$} & $\begin{array}{l}\text { Counts of } \\
\text { Affiliates }\end{array}$ & $\begin{array}{c}\text { Total Value of } \\
\text { Affiliate } \\
\text { Investment^ }^{\wedge}\end{array}$ & $\begin{array}{c}\text { Average } \\
\text { Affiliate } \\
\text { Size* }\end{array}$ & \multirow{2}{*}{$\begin{array}{c}\text { Share }(\%) \text { of } \\
\text { Manufacturing } \\
\text { Trade } \\
10.00\end{array}$} \\
\hline 31 & Food, Bevera & $889(7.43)$ & $11091.99(6.58)$ & 12.476 & \\
\hline 32 & Textile, Apparel, \& Leather & $2,280(19.06)$ & $7078.94(4.20)$ & 3.104 & 4.00 \\
\hline 33 & Wood Products/Furniture & $381(3.18)$ & $4445.45(2.64)$ & 11.667 & 3.00 \\
\hline 35 & Chemical Products & $1,089(9.11)$ & $24532.97(14.57)$ & 22.527 & 13.00 \\
\hline 37 & Basic Metals & $1,175(9.82)$ & $13454.88(7.99)$ & 11.451 & 6.00 \\
\hline 38 & $\begin{array}{l}\text { Fabricated Metal Products/ } \\
\text { Machinery }\end{array}$ & $4.75)$ & $87134.30(51.75)$ & 20.961 & 61.00 \\
\hline \multirow[t]{2}{*}{39} & Miscellaneous Manufacturing & $1,989(16.63)$ & $20633.24(12.25)$ & 10.373 & 3.00 \\
\hline & Total & $11,960(100)$ & $168371.77(100)$ & 14.077 & 100.00 \\
\hline
\end{tabular}

Figures in parentheses are percentages of total in for the respective columns. ${ }^{\wedge}$ - Billions of $¥ *$ - Millions of $¥$.

Source: Trade data from OECD- Bilateral Trade Database-2000. FDI data is from Japanese Ministry of Finance website.

${ }^{8}$ The list of the 35 host countries in our study is presented in the appendix. 
Overall Japanese trade with the 35-host countries in our study accounts for more than 80 per cent of Japanese global trade, with the seven manufacturing industries covered in our study accounting for nearly 98 per cent percent of the Japanese manufacturing trade. At the industry level, Japanese trade in fabricated metal products and machineries (ISIC-38) account for the largest proportion (61 per cent) of the overall Japanese export sales, with the chemical products industries (ISIC35 ) accounting for the next largest proportion (13 per cent) of Japanese exports. While export sales in basic metal industries (ISIC-37) account for 6\%, manufacturing industries in ISIC-39 account only for 3\%. Food, beverage and tobacco (ISIC-31), textile, apparel and leather (ISIC-32), and wood products and furniture (ISIC-33) account for the remaining 10 per cent, 4 per cent and 3 per cent of Japanese industry specific export sales, respectively.

The composition of Japanese outward FDI in our data is highly diverse. Fabricated metal products and machineries as well as textile, apparel and leather industries together constitute about 54 per cent of the total counts of Japanese affiliate establishments. FDI in wood products and furniture, basic metals, and chemical products industries each account for less than 10 per cent of total Japanese manufacturing FDI establishments. In regard to affiliate size, chemical products’ affiliates are the largest ( $¥ 22.52$ million per establishment) among all industry groups, while textile, apparel and leather industries are the smallest (nearly $¥ 3$ million per affiliate). While these results indicate significant variation in the value and average size of investment, there has also been significant disparity in the growth patterns of investment across different industries. ${ }^{9}$ Given the disparity in industry investment patterns over time, the question exists as to what motivates Japanese investors in certain industries to locate a larger proportion of their FDI in a host country that attracts only a small proportion of FDI in other industries. While our main concern in this paper is the empirical examination of the impact of export platform status of the host countries on the FDI-export sales interaction, we also address this issue.

\footnotetext{
${ }^{9}$ Analysis of the data by industry and year shows, for example, that in 1989139 new food/beverage/tobacco affiliates (with an average size of $¥ 125$ million) were established in 19 countries. By 1998, the number of newly established affiliates from this industry had fallen to 44 (in 12 countries) with an average affiliate size of $¥ 134$ million. However, during the same period, the number of newly established affiliates (average affiliate size) in Fabricated Metal products/Machineries increased from 95 ( $¥ 63$ million) to 154 ( $¥ 115$ million).
} 


\section{The Analytical Framework}

\section{A. Theoretical Model}

Consider a cost minimizing multinational firm that observes demand for its product in multiple foreign markets. The firm can meet foreign demand for its product in three ways: (i) by exporting $\left(Q_{d}-D_{d}\right)$, which is the difference between home production $\left(Q_{d}\right)$ and home consumption $\left(D_{d}\right)$, (ii) through production $\left(Q_{f}\right)$ in a foreign market (FDI), and (iii) via both exports and foreign production. Given the geographic fragmentation of world production, it is natural to assume that while selecting the location for its foreign production the firm takes into account that output from its affiliate can also be exported to other foreign markets. The investing firm faces not only the decision on where to locate its foreign affiliate and how much to produce both in the domestic and foreign plants, but also the amount of domestic production to be exported to the affiliate host as well as the amount to be exported from its foreign affiliate (export platform) to $3^{\text {rd }}$-country destinations.

In making such a decision, the firm would need to take into account several factors: its unit domestic $\left(\mathrm{c}_{\mathrm{d}}\right)$ and foreign $\left(\mathrm{c}_{\mathrm{f}}\right)$ costs of production, the trade costs $\left(\mathrm{t}_{1}\right)$ associated with exporting $\left(Q_{d}-D_{d}\right)$ units of output from home to foreign market(s), and the trade costs $\left(\mathrm{t}_{2}\right)$ associated with shipping $(1-\eta) Q_{f}$ units of its output from the foreign host (the country to be used as export platform) to the $3^{\text {rd }}$ party market(s). Therefore, following Tadesse and Ryan (2004), the total costs (C) function of the firm could be represented as follows:

$$
C=c_{d}\left(Q_{d}\right) Q_{d}+c_{f}\left(Q_{f}\right) Q_{f}+t_{1}\left(Q_{d}-D_{d}\right)+t_{2}\left\{\left(1-\eta\left(t_{2}, \theta\right)\right) Q_{f}\right\}
$$

where $\theta$ represents the host's specific-characteristics, $t_{2}$ are the trade costs associated with exporting a unit of output to third-country markets, and $\left(0 \leq \eta\left(t_{2}, \theta\right) \leq 1\right)$ refers to the amount of the firm's production in the foreign host that is consumed in the foreign host itself (and thus $\left[\left(1-\eta\left(t_{2}, \theta\right)\right) Q_{f}\right]$ is the amount that the firm's affiliate exports to $3^{\text {rd }}$ country markets from where it is located). ${ }^{10}$

Given its cost of production in equation (1) for serving the domestic and foreign

\footnotetext{
${ }^{10}$ Higher transport costs, trade barriers between the foreign host and third party markets, and other constraints arising from the political economy of regional trade may decreases the host's likelihood of being an export platform.
} 
markets, the firm would need to balance the total output (production from the domestic and foreign plants) with the total demand (D) so that:

$$
Q_{d}+Q_{f}=D
$$

Minimizing its costs in equation (1) subject to the constraint in equation (2), and solving for the first-order conditions, Tadesse and Ryan (2004) show that the equilibrium level of output for the firm's foreign affiliate would be:

$$
Q_{f}=\gamma_{1}\left[t_{1}-\left(1-\eta\left(t_{2}, \theta\right)\right) t_{2}\right]+\gamma_{2}\left(c_{d}-c_{f}\right)+\gamma_{3} D
$$

Further assuming a Cobb-Douglas production technology to be employed by the foreign affiliate, Tadesse and Ryan (2004) also show that the optimal amount of capital (FDI) to be invested in the foreign affiliate (subsidiary) as:

$$
K_{f}=\left[\frac{\beta}{\alpha} \frac{\left(w_{f}\right)}{\left(q_{f}\right)}\right]^{\alpha /(\alpha+\beta)}\left\{\gamma_{1}\left[t_{1}-\left(1-\eta\left(t_{2}, \theta\right)\right) t_{2}\right]+\gamma_{2}\left(c_{d}-c_{f}\right)+\gamma_{3} D\right\}^{1 /(\alpha+\beta)}
$$

where, $K_{f}$ is capital (FDI), $w_{f}$ is a wage rate for labor, $q_{f}$ is a real user cost of capital, and $\gamma_{1}=\gamma_{2}=\frac{1}{\left(c_{d}{ }^{\prime}+c_{f}{ }^{\prime}\right)}$ and $\gamma_{3}=\frac{c_{d}{ }^{\prime}}{\left(c_{d}{ }^{\prime}+c_{f}{ }^{\prime}\right)}$.

Generalizing the functional relationship described in equation (4) we can present the firm's investment (FDI) into a given foreign host country $i$ (irrespective of its export platform status) as follows: ${ }^{11}$

$$
F D I_{i}=f\left(\mathbf{X}_{\mathbf{i}}, \mathbf{D}_{i}\right)
$$

where, $\mathbf{X}_{\mathrm{i}}$ refers to a vector of variable related to various home host attributes, and $\mathrm{D}$ refers to the aggregate export supply (import demand) from the FDI source to the FDI host.

\section{B. The Empirical Model}

We define our two-step analytical approach in such a way that it enables us to answer both of our questions. First, following the general literature in the area, we attempt to answer if Japanese outward FDI and export sales (trade) interaction is industry specific. Thus, for each of the seven 2-digit ISIC Japanese manufacturing industries, we regress the industry- specific proportion of the financial value of Japanese FDI received by each host on a set of country- and industry-specific attributes. While the estimating equation for our data is a natural extension of the

\footnotetext{
${ }^{11}$ Wheeler and Mody (1992) also model outward FDI values as a relative function of classical location choice and country risk (uncertainty) variables.
} 
theoretical model in equation (5), the assumption underlying our use of the host's industry specific share of Japanese FDI as the dependent variable follows Mody and Srinivasan (1998): each industry first decides on the extent of total investment abroad and then on the allocation of that investment to different countries. Unlike Mody and Srinivasan (1998), however, we control for the export platform status of the host countries. Therefore,

$$
Y_{i t}^{(j)^{*}}=X_{i t}^{(j) \prime} \alpha+Z_{i t}{ }^{\prime} \gamma+\varepsilon_{i t}^{(j)}+u_{i}^{(j)}
$$

where $Y_{i t}^{(j)^{*}}$ denotes industry (j)'s value of Japanese FDI received in a host country $i$ during a given year t; (i.e., industry (j)'s share of the host's overall inward FDI). ${ }^{12}$ $X_{i t}^{(j)}$ and $Z_{i t}$ respectively denote vectors of industry- and host-country specific attributes hypothesized to affect the inflow of FDI into each host country. While variables in $Z_{i t}$ do not vary from industry to industry, variables in $X_{i t}^{(j)}$ are industry specific. Finally, $\varepsilon_{i t}^{(j)}$ is a random error term with zero mean and constant variance $\sigma_{\varepsilon}^{2} ; u_{i}^{(j)}$ is a random, country specific effect with zero mean and constant variance $\sigma_{u}^{2}$; finally, $\alpha$ and $\gamma$ are unknown parameters to be estimated. ${ }^{13}$ It is assumed that $\varepsilon_{i t}^{(j)}$ are $u_{i}^{(j)}$ independent.

One of the variables in the vector $X_{i t}^{(j)}$ is industry-specific export sales. ${ }^{14}$ To evaluate whether the impact of Japanese industry specific export sales on the inflow of industry specific Japanese FDI into the respective host county is industry specific or not, we first estimate $\alpha$ for each of the seven $(j=1, \ldots, 7)$ industries. This allows us to conduct a pair-wise $t$ test on the equality (in magnitudes and signs) of the coefficient estimates of the export sales variable (i.e., $\alpha^{(1)}=\alpha^{(2)} ; \alpha^{(1)}=$ $\left.\alpha^{(3)} ; \ldots ; \alpha^{(1)}=\alpha^{(j)}\right)$ for all the industry pairs. In the event that the null hypothesis of equality between the coefficient pairs is rejected, we conclude that the FDI-export sales interaction is industry specific.

Second, we investigate whether the host's export platform status affect the FDIexport sales interaction? To answer this question, we adopt the same empirical model (eq. 6) discussed above and concentrate on the coefficient estimate of the export sales variable, and the interaction between the industry-specific export sales variable and the dummy variable denoting the host's export platform status. The

\footnotetext{
${ }^{12} \mathrm{~A}$ description of the procedure used to derive the dependent variable is discussed in the appendix.

${ }^{13}$ The superscript (j), enclosed in a parenthesis, indicates that the model to be estimated is industry specific. Therefore, the panel has only two dimensions: the cross section $[i]$ and the time series $[t]$.

${ }^{14}$ This refers to total Japanese exports at the ISIC-2 digit level industry and is measured in thousands of constant U.S. dollars.
} 
host's export platform status defines whether Japanese affiliates located in each host largely service third-party markets (use the host as gateways [export platforms] to service other markets), or use service the host-market itself and/or produce and export back to Japan. ${ }^{15}$

Thus, in the framework of the generalized equation (6), our estimating equation could be expressed as follows:

$$
Y_{i t}^{(j)^{*}}=X_{i t}^{(j) \prime} \alpha+Z_{i t}{ }^{\prime} \gamma+D_{i t}{ }^{\prime} \delta+\left(D_{i t} * X_{1 i t}^{(j)}\right)^{\prime} \beta_{1}+\varepsilon_{i t}^{(j)}+u_{i}^{(j)}
$$

Given the estimating equation (7), the partial derivative of the dependent variable with respect to each variable of interest would give us the marginal effects of each variable. The sign and the significance of the coefficient estimates (marginal effects) of the export sales variable would enable us to identify whether the industry specific export sale is complementary, substitute or neutral to the proportion of industry specific Japanese FDI received by each host.

In equation (7), the dependent variable is observable only when the value of investment in each affiliate created is not censored. Data censoring could occur for several reasons, such as when investment in a given host is made exclusively by a single firm, or when investment levels fall below a certain threshold. In these cases, the data source reports the amount of investment as NA (not available), and since we re-coded the NA values to zero in our dataset, a zero FDI value does not necessarily imply zero investment. To account for the censoring of our dependent variable, we employ a Tobit model. The empirical Tobit estimating equation for the model in equation (6 or 7) can be represented as follows:

$$
Y_{i t}^{(j)}=A\left(\alpha+Z_{i t}{ }^{\prime} \gamma+X_{i t}^{(j)} \beta^{(j)}+\sigma \lambda_{i t}^{(j)}\right)
$$

where

$$
\begin{gathered}
Y_{i t}^{(j)}=Y_{i t}^{(j)^{*}} \text { if }\left\{\begin{array}{c}
Y_{i t}^{(j)} \leq 0 \\
\text { and } \\
Y_{i t}^{(j)}>0
\end{array}\right\} ; A=\Phi\left(\frac{\alpha+Z_{i t}{ }^{\prime} \gamma+X_{i t}^{(j)} \beta^{(j)}}{\sigma}\right) \text { and } \\
\lambda_{i t}^{(j)}=\frac{\phi\left(\frac{\alpha+Z_{i t}{ }^{\prime} \gamma+X_{i t}^{(j)} \beta^{(j)}}{\sigma}\right)}{\Phi\left(\frac{\alpha+Z_{i t}{ }^{\prime} \gamma+X_{i t}^{(j)} \beta^{(j)}}{\sigma}\right)}
\end{gathered}
$$

\footnotetext{
${ }^{15}$ We discuss how export platform status is determined in detail in section 4.3.
} 
Here $\phi$ is the standard normal density function (CDF); $\Phi$ is cumulative standard $\mathrm{CDF} ; \sigma$ is the standard error of the estimate, and all other variables are as defined earlier. Given the panel nature of our data, estimation of the unknown parameters in the empirical model could be done either as a pooled Tobit or random effects Tobit regression. ${ }^{16}$ The choice between the pooled and random effects Tobit model is based on the significance of the variance at the country level $\left(\sigma_{u}^{2}\right)$. Description of the empirical model and data used in the analysis is provided below.

\section{Data and Variable Description}

We use annual industry specific (ISIC-2 digit level) outward Japanese FDI in seven manufacturing industries for the period 1989-1998 as our dependent variable. The choice of the reference period is dictated by data availability for both the dependent and the explanatory variables. The FDI data is obtained from Japanese Ministry of Finance website. The corresponding trade data is from the OECD Commodity Trade Statistics, while all other country specific data are from a variety of sources listed in the Appendix. While all the industry specific variables vary over time, several of the country-specific variables do not. As country specific variables are industry invariant, variation in their respective coefficient estimates across the different equations would reflect differences in the sensitivity of industry specific FDI to general host country attributes, enabling us to address how host country attributes affect the proportion of Japanese FDI that went to different countries in each industry.

The list and descriptive statistics of all the variables included in the empirical model are provided in Table 2. Below we provide a brief definition of some of the explanatory variables and how we construct them.

Host's Export Platform (EP) status: We identify a host's export platform status following the descriptions of Japanese FDI host countries in UNCTAD (1996, 2001), and MIGA (2002). Accordingly, we identify four host "types", where located in each host is production primarily designed to: (1) serve the host country, (2) be exported back to Japan, (3) service the host's geographically regional market, and (4) service the host's geographically non-region market. For

\footnotetext{
${ }^{16}$ Estimation of the fixed effects Tobit model is not feasible. The fixed effects Tobit estimation of the unknown individual effects parameters requires $\mathrm{T}$, the time dimension, to be large. However, as is common in most panel data, $\mathrm{T}$ is usually limited. Thus any estimation of the fixed individual effects parameters in a Tobit regression is inconsistent (Hsiao, 1986).
} 
our purposes, we combine categories (3) and (4) into a single "export platform" category, as these hosts serve as destinations for Japanese FDI targeting third-party countries. For each host, the ExportPlatform dummy variable takes the value 1 if the country is characterized as an export platform (ExportPlatform=1) and 0 otherwise. Given Ekholm et al.'s (2003) assertion that export platforms incorporate both horizontal and vertical FDI tendencies, we maintain no a priori expectation on the signs of the dummy denoting the export platform status of the host countries. ${ }^{17}$

Table 2. Descriptive Characteristics of the Variables in the Model (Annual Averages)

\begin{tabular}{|c|c|c|c|}
\hline \multirow{2}{*}{$\begin{array}{l}\text { Variable Definition } \\
\text { Industry-Level Attributes: }\end{array}$} & \multicolumn{3}{|c|}{ Average Values Minimum Maximum } \\
\hline & & & \\
\hline $\begin{array}{l}\text { Host country share of industry specific Japanese FDI } \\
\text { counts (per cent) }\end{array}$ & $2.86(6.95)$ & 0.00 & 78.18 \\
\hline $\begin{array}{l}\text { Host country share of industry specific Japanese FDI } \\
\text { value (per cent) }\end{array}$ & $9.86(8.52)$ & 0.00 & 77.77 \\
\hline $\begin{array}{l}\text { Industry specific (ISIC-2digit level) export sales of } \\
\text { Japan }\end{array}$ & $124.36(623.91)$ & 0.00 & $10,330.51$ \\
\hline Industry specific (ISIC-2digit level) imports of Japan & $66.61(220.00)$ & 0.00 & $3,732.53$ \\
\hline EP to other markets (Regional/Non-regional) - Dummy & $0.44(0.50)$ & 0.00 & 1.00 \\
\hline Non EP (FDI Host/FDI Source) - Dummy & $0.56(0.43)$ & 0.00 & 1.00 \\
\hline \multicolumn{4}{|l|}{ Country-Level Attributes: } \\
\hline Average annual exchange rate (Yen/FC) & $44.19(74.90)$ & 0.00 & 642.83 \\
\hline SD of the log difference of monthly exchange rate & $0.04(0.60)$ & 0.00 & 11.20 \\
\hline Index of economic potential (in 1000s) & $9.26(7.35)$ & 0.90 & 34.75 \\
\hline Distance between the host and Japan (in $1000 \mathrm{Km}$ ) & $8.33(3.634)$ & 1.15 & 1.83 \\
\hline Total road network road/area of the host country & $1.05(1.11)$ & 0.08 & 4.98 \\
\hline Total population (in millions) & $101.40(241.33)$ & 0.25 & $1,242.18$ \\
\hline Tariff rate on merchandize imports (per cent) & $12.13(11.45)$ & 0.00 & 98.80 \\
\hline Labor force in the primary sector (per cent) & $16.04(18.15)$ & 0.00 & 69.50 \\
\hline Lending rate (per cent) & $12.35(29.89)$ & 4.96 & 23.40 \\
\hline Political stability index & $0.78(0.70)$ & -1.29 & 1.51 \\
\hline Index of anti-corruption measures & $0.98(0.89)$ & -0.80 & 2.13 \\
\hline Hosts Affinity to Japan (Ratio) & $0.79(1.85)$ & 0.08 & 32.15 \\
\hline Hosts integration with the rest of the world (Ratio) & $0.50(0.04)$ & 0.31 & 0.61 \\
\hline
\end{tabular}

Source: Authors Computation; EP= Export Platform; FC= Foreign currency; SD=Standard Deviation

\footnotetext{
${ }^{17} \mathrm{~A}$ country's EP status may be endogenously determined by the activity of the same foreign affiliates that are included in the dataset. However, as we are examining the link between FDI and "exports sales to the FDI host", not the link between FDI and "affiliate sales from host", we do not think that this significantly impacts our regression results.
} 
Host's Trade Affinity with Japan: The host's trade affinity with Japan is defined as the ratio of the host's annual total trade (exports and imports) with Japan to the host's trade with the rest of the world (excluding Japan). Markusen (1990) asserts that the presence of strong trade ties between a regional economy and the FDI source might promote a firm's decision to locate its affiliate there. Thus, we expect hosts with relatively strong trade ties with Japan to attract larger proportion of Japanese FDI and thus the variable is a priori expected to have a positive sign.

Host's Global Integration: This variable proxies the extent to which each host's local production activities are integrated into the global economy. ${ }^{18}$ Wheeler and Mody (1991) indicate that the presence of more suppliers in a given host can create finer divisions of labor in intermediate input markets, thereby lowering final goods unit production costs. Thus, the extent of the host's global integration can affect an industry's decision on where to locate their affiliates. Certain industries may prefer to locate a larger proportion of their investment in a particular host because a higher degree of global integration may provide a comparative advantage in serving the world market. We derive the variable by taking the ratio of total exports of each host (excluding those to Japan) to its Gross Domestic Product (GDP).

Host's Institutional Attributes: The host's policies and macroeconomic environments within which foreign firms are required to operate affect the incentives of the foreign firm to invest in the given host. We use political instability and anticorruption measures as variables that reflect institutional attributes in each host. Each measure ranges in value from -3 to 3 and both variables are as reported in Kaufmann, Kraay and Zoido-Lobaton (1999). A priori we expect a negative sign for the political instability index, while the index for anti-corruption measures is expected to have a positive sign.

Other Host Country Attributes: This group of country-specific variables includes the great circle distance between the host's capital city and Tokyo (a measure of transportation cost); the host's population (a proxy for the host's market size); the host's proportion of labor in the primary production sector, its lending rate (proxies for unit production costs), and its road network density relative to the

\footnotetext{
${ }^{18} \mathrm{GDP}$ is measured in 1995 U.S. dollars (USD).
} 
total area of a country (a proxy for infrastructure). In addition, we also use host specific un-weighted tariff rate on merchandize imports as a measure of the degree to which local producers in each host are exposed to external competition. ${ }^{19}$ Together with market size, the openness of the host market determines the return from investment, and thus the location choice or investment levels. A priori, we expect distance, lending costs, and employment in the primary sector to have a negative impact on FDI location, while greater infrastructure should act to attract FDI. A host's openness (the degree to which local producers are exposed to external competition) is a relevant determinant of the expected investment return. When markets are protected, FDI is often tariff jumping in nature since profits of local producers are enhanced by limitations on competitive imports (Blonigen, 2002). Thus we expect the coefficient of the tariff rate variable to be positive.

\section{Empirical Results}

For each industry, we first obtain the maximum likelihood estimates of the coefficients of the explanatory variables using a panel Tobit regression. The regression model is either a pooled or a random effects Tobit model depending upon the significance of the variance $\left(\sigma_{u}^{2}\right)$ at the country level ${ }^{20}$ In three of the seven industries, namely ISIC-31 (food/beverage/tobacco industries), ISIC-35 (chemical products) industries, and ISIC-39 (miscellaneous manufacturing industries), the likelihood ratio test result shows that the country level variance $\left(\sigma_{u}^{2}\right)$ is not significantly different from zero. This indicates that for these industries there is little country specific heterogeneity. Thus, for each industry, we estimate a pooled cross section Tobit regression. For textile, apparel and leather (ISIC-32), wood product/furniture (ISIC-33), basic metals (ISIC-37), and fabricated metal products/machinery (ISIC-38) industries, however, there appears to be significant host-country specific heterogeneity. Hence, for these industries, we estimate

\footnotetext{
${ }^{19}$ This could also be taken as a proxy for openness of the host market. The tariff rates are not specific to imports from Japan.

${ }^{20}$ When the variance at the country level $\sigma_{u}{ }^{2}$ is significant, the random effects model is more efficient than the pooled model and thus we estimate our model as a random effect Tobit. When the variance at the country level $\sigma_{u}{ }^{2}$ is not significant, random effect Tobit model do not yield any better estimate over a pooled model. Rho, defined as $\rho=\sigma_{u}^{2} /\left(\sigma_{\varepsilon}^{2}+1\right)$, also provides similar information. It measures the percent contribution of the country level variance to the total variance. When rho is zero, the variance at the country level (panel-level variance) is unimportant and thus the panel estimator is not different from the pooled estimator.
} 
random effect Tobit model. Log-likelihood ratio and the Wald chi-square test results on the performance of each of the models and the joint significance of the explanatory variables included in each of the models indicate that our explanatory variables are jointly significant and each model also fits the data well.

\section{A. Industry specific FDI-export sales interaction}

To test whether the FDI-export sales interaction is industry specific, first we obtain the maximum likelihood estimate of the coefficient of export sales variable from each industry-level regression. Then, we conduct a pairwise t-test on the null hypothesis that the effect of industry specific export sales on FDI does not differ from industry to industry. Table 3 provides the t-test statistic values for the coefficients. ${ }^{21}$ With the exception of the wood products/furniture industry (ISIC33 ), our results reject the null hypothesis at at $p<0.05$. Therefore, we conclude that the link between FDI and export sales is industry specific.

Having determined that the FDI-export sales interaction is industry specific, we turn to the discussion of the exact nature of the interaction. To make inferences about the exact nature of the FDI-export sales interaction in each industry, we use the coefficient estimates from a panel Tobit regression. As we conduct our analysis without accounting for the host's export platform status, analysis is in line with the available literature. In Table 4 we present the coefficient estimates.

Results in the table indicate that Japanese FDI in food/beverage/tobacco (ISIC-

Table 3. Pair wise t-test statistics on the effects of industry specific export sales across the seven manufacturing industry groups

\begin{tabular}{cccccccc}
\hline & ISIC-31 & ISIC-32 & ISIC-33 & ISIC-35 & ISIC-37 & ISIC-38 & ISIC-39 \\
\hline ISIC-31 & 0.00 & $4.04 * *$ & 1.38 & $4.71^{* *}$ & $5.22^{* *}$ & $4.84^{* *}$ & $4.63^{* *}$ \\
ISIC-32 & & 0.00 & 1.16 & $15.50^{* *}$ & $30.50^{* *}$ & $20.24^{* *}$ & $17.26^{* *}$ \\
ISIC-33 & & & 0.00 & 1.11 & 1.02 & 1.11 & $1.99^{* *}$ \\
ISIC-35 & & & & 0.00 & $74.93^{* *}$ & $22.58^{* *}$ & $18.85^{* *}$ \\
ISIC-37 & & & & & 0.00 & $94.15^{* *}$ & $19.65^{* *}$ \\
ISIC-38 & & & & & & 0.00 & $19.10^{* *}$ \\
ISIC-39 & & & & & & & 0.00 \\
\hline
\end{tabular}

Source: Authors Computation. Figures in the table are $\mathrm{t}$ statistics. $* *$ Denote significance at $p<0.05$.

\footnotetext{
${ }^{21}$ The significance of the test statistic values indicates whether the export sales coefficient estimates differ across industries. We conduct these tests because, in the event that the FDI-export sales interaction is not industry specific (i.e., if there are no significant differences between the coefficient estimates of the export sales variable across industries), aggregation of both FDI and export sales (trade) to a country level is justifiable.
} 
Table 4. Panel Tobit Estimates of the Determinants of Industry Specific Host-Country share of Japanese outward FDI (1989-1998)

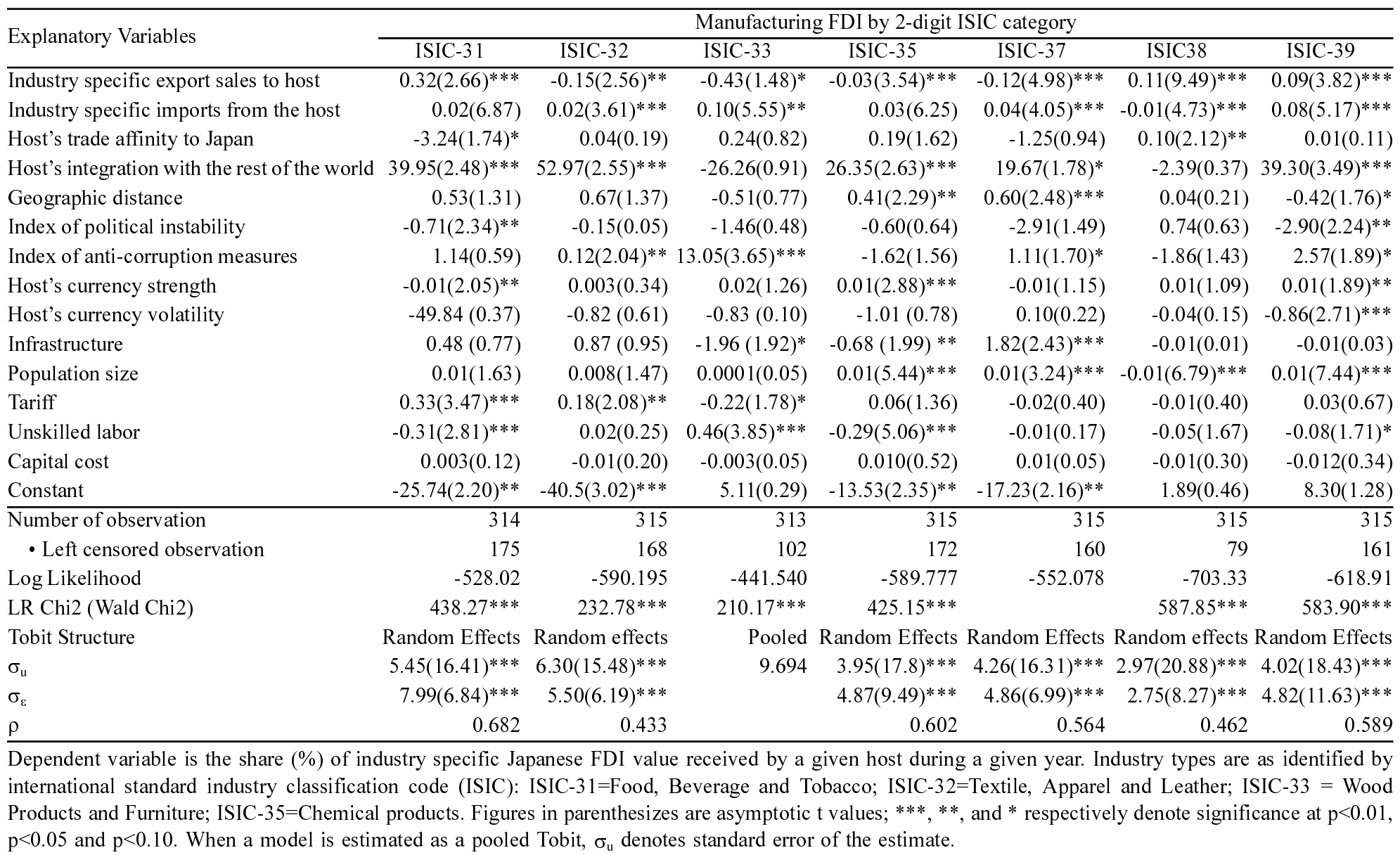


31), fabricated metal products (ISIC-38) and miscellaneous manufacturing (ISIC39) industries complement Japanese industry specific export sales. For textile/ apparel/leather (ISIC-32), wood products/furniture (ISIC-33), chemical products (ISIC-35) and basic metals (ISIC-37) industries, however, the export sales coefficient is negative and significant, indicating that FDI and industry-specific export sales are substitutes. Among the later group of manufacturing industries, basic metal products industries (ISIC-37) generally produce relatively bulkier and heavier goods with the substitute relationship the result of investors' interest to minimize transportation costs. It may also be that Japanese FDI Japanese FDI in basic metal industries follows an efficiency-seeking (rather than market-seeking) investment model. Among many of the variables that denote the host's institutional conditions while legal barriers to trade tariff rates encourage increased investment in many of the industries, their impact on investment from firms in the chemical products/pharmaceutical (ISIC-35), basic metals (ISIC-37), and fabricated metal products (ISIC-38) industries is not significant.

\section{B. Host's export platform status and the FDI-export sales interaction}

Based on the results in Table 4, the exact nature of Japanese industry specific FDI and export sales interaction varies from industry to industry (i.e., while FDI and exports are substitutes in some industries, they are complementary in others). These results may depend upon FDI location choice determinants differing across industries. In general, investors may chose a location for their foreign affiliates based on one (or more) of the following reasons: (i) a demand for their products exists in the host's local market, (ii) the host provides a cost advantage for processing the final products whose main demand is located in the FDI source market itself, and (iii) the host is a gateway to multiple other markets and thus producing in such a host provides easy access to third country markets. ${ }^{22}$ Data pertaining to which of these factors principally motivates investors to locate larger proportion of their FDI in a given host is difficult to obtain. However, recent evidence from Helpman, Melitz, and Yeaple (2004) indicate that irrespective of whether firms are market- or resource-seeking, some investors are attracted to certain hosts because the host serves them as gateway to third country markets. This indicates that the amount of FDI that the host receives might be affected by its

\footnotetext{
${ }^{22}$ Without taking this into account, earlier research in the area simply defines FDI as vertical and/or horizontal, and thereby defines the potential link between FDI and trade as either complements or substitutes.
} 
export platform status. Thus, it is possible that differences in the host's suitability to serve as a gateway to third-party markets might also affect the nature of its inward FDI-import sales interaction.

In this section we account for the host's export platform status and re-evaluate the industry specific FDI-export sales interaction. We also examine the extent to which the host's export platform affects the amount of industry-specific FDI it receives. Coefficient estimates derived from the panel Tobit models in which we control for the hosts' export platform status, and its interaction with industry specific export sales, is presented in Table 5.

Results in the table indicate that the host's export platform status significantly influences both the FDI-industry specific export sales interaction and the amount of industry specific FDI that the host receives. For most of the industries in our analysis, after we account for the export platform status of each host, the significance of the export sales variable remains fairly stable. However, with the export platform status dummy and the export platform-export sales interaction variable included, inference on whether FDI complements or substitutes export sales cannot be made solely from the export sales coefficient. Instead we compute the marginal effects of the export sales variable and the export sales - export platform status interaction variable.

Accordingly, we observe three important changes in the conclusion we made earlier. First, in ISIC-32 (textile/apparel/leather industries) and ISIC-33 (wood products/ furniture industries), we observe changes in both the magnitude and sign of the export sales variable, implying that FDI does not substitute for export sales as observed earlier. In both industries, the marginal effects of the export sales variable change from negative (-0.1301 for ISIC-32 and -0.3001 for ISIC-33) to positive ( 0.0322 for ISIC-32 and 0.2214 for ISIC-33), suggesting that FDI complements export sales. Second, for ISIC-39 (miscellaneous manufacturing) the marginal effect changes from a positive value (0.006) to a negative value (-0.975), implying that FDI and export sales in these industries are substitutes rather than complements. Third, for ISIC-38 (fabricated metal products), although the marginal effects of the export sales variable retains its sign, the coefficient is not significant enough to allow us make an inference as to whether FDI and export sales are complementary as observed earlier. In the remaining three other industry types, namely ISIC-31 (food/beverage/tobacco industries), ISIC-35 (chemical product industries), and ISIC-37 (basic metal industries) accounting for the host export platform status and its interaction with export-sales variable, does not 
Table 5. Panel Tobit Estimates of the Determinants of Industry Specific Host Country share of Japanese outward FDI Value (1989-1998)

\begin{tabular}{|c|c|c|c|c|c|c|c|}
\hline \multirow{2}{*}{ Explanatory Variables } & \multicolumn{7}{|c|}{ Manufacturing FDI by 2-digit ISIC category } \\
\hline & ISIC-31 & ISIC-32 & ISIC-33 & ISIC-35 & ISIC-37 & ISIC38 & $\begin{array}{l}\text { ISIC-39 } \\
\end{array}$ \\
\hline Industry specific export sales to host & $0.21(2.86)^{* * *}$ & $0.05(1.57)$ & $0.49(1.35)$ & $-0.01(3.55)^{* * *}$ & $0.09(4.88)^{* * *}$ & $0.01(8.41)^{* * *}$ & $0.05(4.28)^{* * *}$ \\
\hline Export Platform & $2.45(3.82)^{* * *}$ & $-6.35(2.88)^{* * *}$ & $-7.43(4.05)^{* * *}$ & $3.69(4.08)^{* * *}$ & $-2.67(0.52)$ & $-1.51(2.88)^{* * *}$ & $-1.03(2.03)^{* *}$ \\
\hline Export Sales* Export Platform & $-0.110(1.73)$ & $0.051(2.36)^{* *}$ & $0.475(0.74)$ & $-0.34(2.65)^{* * *}$ & $-2.701(1.43)$ & $-3.034(0.82)$ & $-5.47(4.05)^{* * *}$ \\
\hline $\begin{array}{l}\text { Value of Japanese industry specific imports } \\
\text { from the host }\end{array}$ & $0.02(6.87)$ & $0.02(3.61)^{* * *}$ & $0.10(5.55)^{* *}$ & $0.03(6.25)$ & $0.04(4.05)^{* * *}$ & $-0.01(4.73)^{* * *}$ & $0.08(5.17)^{* * *}$ \\
\hline Host's trade affinity to Japan & $-3.24(1.74)^{*}$ & $0.04(0.19)$ & $0.24(0.82)$ & $0.19(1.62)$ & $-1.25(0.94)$ & $0.10(2.12)^{* *}$ & $0.01(0.11)$ \\
\hline Host's integration with the rest of the world & $39.95(2.48)^{* * *}$ & $52.97(2.55)^{* * *}$ & $-26.26(0.91)$ & $26.35(2.63)^{* * *}$ & 19.67(1.78)* & $-2.39(0.37)$ & $39.30(3.49)^{* * *}$ \\
\hline Geographic distance & $0.53(1.31)$ & $0.67(1.37)$ & $-0.51(0.77)$ & $0.41(2.29)^{* *}$ & $0.60(2.48)^{* * *}$ & $0.04(0.21)$ & $-0.42(1.76)^{*}$ \\
\hline Index of political instability & $-0.71(2.40)^{* *}$ & $-0.15(0.05)$ & $-1.46(3.48)^{* *}$ & $-0.60(0.64)$ & $-2.91(1.49)$ & $0.74(0.63)$ & $-2.90(2.24)^{* *}$ \\
\hline Index of anti-corruption measures & $1.14(0.59)$ & $0.12(2.04)^{* *}$ & $13.05(3.65)^{* * *}$ & $-1.62(1.56)$ & $1.11(1.71)^{*}$ & $-1.86(1.43)$ & $2.57(1.89)^{*}$ \\
\hline Host's currency strength & $-0.01(2.05)^{* *}$ & $0.003(0.34)$ & $0.02(1.26)$ & $0.01(2.88)^{* * *}$ & $-0.01(1.15)$ & $0.01(1.09)$ & $0.01(1.89)^{* *}$ \\
\hline Host's currency volatility & $-49.84(0.37)$ & $-0.82(0.61)$ & $-0.83(0.10)$ & $-1.01(0.78)$ & $0.10(0.22)$ & $-0.04(0.15)$ & $-0.86(2.71)^{* * *}$ \\
\hline Infrastructure & $0.48(0.77)$ & $0.87(0.95)$ & $-1.96(1.92)^{*}$ & $-0.68(1.99) * *$ & $1.82(2.43)^{* * *}$ & $-0.01(0.01)$ & $-0.01(0.03)$ \\
\hline Population size & $0.01(1.63)$ & $0.008(1.47)$ & $0.0001(0.05)$ & $0.01(5.44)^{* * *}$ & $0.01(3.24)^{* * *}$ & $-0.01(6.79)^{* * *}$ & $0.01(7.44)^{* * *}$ \\
\hline Tariff & $0.33(3.47)^{* * *}$ & $0.18(2.08)^{* *}$ & $-0.22(1.78)^{*}$ & $0.06(1.36)$ & $-0.02(0.40)$ & $-0.01(0.40)$ & $0.03(0.67)$ \\
\hline Unskilled labor & $-0.31(2.81)^{* * *}$ & $0.02(0.25)$ & $0.46(3.85)^{* * *}$ & $-0.29(5.06)^{* * *}$ & $-0.01(0.17)$ & $-0.05(1.67)$ & $-0.08(1.71)^{*}$ \\
\hline Capital cost & $0.003(0.12)$ & $-0.01(0.20)$ & $-0.003(0.05)$ & $0.010(0.52)$ & $0.01(0.05)$ & $-0.01(0.30)$ & $-0.012(0.34)$ \\
\hline Constant & $-25.74(2.20)^{* *}$ & $-40.5(3.02)^{* * *}$ & $5.11(0.29)$ & $-13.53(2.35)^{* *}$ & $-17.23(2.16)^{* *}$ & $1.89(0.46)$ & $8.30(1.28)$ \\
\hline Number of observation & 314 & 315 & 313 & 315 & 315 & 315 & $\overline{315}$ \\
\hline - Left censored observation & 175 & 168 & 102 & 172 & 160 & 79 & 161 \\
\hline Log Likelihood & -528.02 & -590.195 & -441.540 & -589.777 & -552.078 & -703.33 & -618.91 \\
\hline LR Chi2 (Wald Chi2) & $438.27 * * *$ & $232.78 * * *$ & $210.17 * * *$ & $425.15 * * *$ & & $587.85 * * *$ & $583.90 * * *$ \\
\hline Tobit Structure & Random Effects & Random effects & PooledI & Random Effects & Random Effects I & Random effects & Random Effects \\
\hline$\sigma_{\mathrm{u}}$ & $6.34(15.41)^{* * *}$ & $6.33(15.48)^{* * *}$ & 9.694 & $3.95(17.6)^{* * *}$ & $4.56(16.31)^{* * *}$ & $2.98(20.88)^{* * *}$ & $4.07(18.43)^{* * *}$ \\
\hline$\sigma_{\varepsilon}$ & $7.67(6.84)^{* * *}$ & $5.51(6.19)^{* * *}$ & & $4.87(9.9)^{* * *}$ & $4.75(6.99)^{* * *}$ & $2.76(8.27)^{* * *}$ & $4.88(11.63)^{* * *}$ \\
\hline$\rho$ & 0.682 & 0.421 & & 0.702 & 0.577 & 0.462 & 0.599 \\
\hline
\end{tabular}

Dependent variable is the share of industry specific Japanese FDI value (percent) received by a given host during a given year. Figures in parenthesizes are asymptotic $\mathrm{t}$ values; $* * *, * *$, and $*$ respectively denote significance at $\mathrm{p}<0.01, \mathrm{p}<0.05$ and $\mathrm{p}<0.10$. When a model is estimated as a pooled Tobit, $\sigma_{\mathrm{u}}$ denotes standard error of the estimate. 
change the relationship between FDI-export sales interaction.

Overall, changes in the effect of export sales variable on FDI, and thereby the exact nature of the FDI-export sales interaction when controlling for the host's export platform status, suggests that such status is important. Although theoretical justifications for why export platform status affects the FDI-trade link are clearly not well-established, such effects appear in the empirical data. For example, it is recognized that a large percentage of Japanese FDI into many countries (e.g., Mexico, Ireland) is truly designed to service these nation's geographically regional (and larger) markets (the U.S and the EU, respectively) rather than Japan or the host itself. In fact, its role as an export platform may be the reason that Waldkirch (2003) finds that neither the horizontal nor vertical FDI models can be rejected in explaining inward Mexican FDI.

However, our results indicate that the impact of the export platform on the likelihood of the host to receive higher proportion of FDI also varies from industry to industry. We observe that export platform nations receive proportionally larger amounts of FDI in several industries (ISIC-31 and ISIC-35), and less in other industries (ISIC-32, ISIC-33, ISIC-38, ISIC-39), as compared to non-export platform hosts. This disparity among industries is perhaps the result of differences across hosts' comparative advantages and investment climate. As a result, a country's export platform status may not pertain to all industries. For example, Japanese FDI into Brazil encompasses all three FDI motivations, suggesting that even in recognized export platform countries, not all investment are geared toward serving third-party markets. ${ }^{23}$ As a result, by virtue of differences in the opportunities that a given host might provide to investors whose interest is to service third party markets (rather than the FDI source or the host market itself), certain host nations are able to attract larger proportion of certain industries than others.

\section{Other FDI determinants}

Inference on the coefficient estimates of the other host country attributes also provides some important insight on the role of certain FDI determinants. Overall the responsiveness of Japanese outward FDI to variations in host country attributes significantly differs across the different manufacturing industry groups. Coefficient

\footnotetext{
${ }^{23}$ See 'Brazil-Japan: "Alliance for the 21st century", Japan-Brazil Economic Committee, Keidanren, October 26, 2000. (http://www.keidanren.or.jp/english/policy/2000/053.html). Keidanren (Japan Federation of Economic Organizations) merged with Nikkeiren (Japan Federation of Employers' Associations) to form the Japan Business Federation in 2002.
} 
estimates in both Tables 4 and 5 indicate that the host's likelihood of attracting Japanese FDI increases with its trade affinity with the FDI source (Japan) country as well as the host's integration with the global market. This propensity, however, differs across industries. For example, investors in fabricated metal products and machinery industries have higher propensity to concentrate larger proportion of their FDI in hosts that have stronger trade affiliation with Japan. Japanese FDI in food, beverage and tobacco (ISIC-31), basic metal (ISIC-37) and miscellaneous manufacturing (ISIC-39), however, have higher likelihood of being located in hosts that are more integrated with the rest of the world.

Also, there appears to be significant trade-offs between the likelihood of locating larger proportion of industry specific FDI and transport cost for exporting goods to the host market, as the marginal effects vary from 0.559 for food, beverage and tobacco industries to 2.339 for wood products and furniture industries. In addition, geographic distance appears to have a positive and significant coefficient in three (ISIC-35 -37, -39) industries, confirming that Japanese investors' decisions to locate larger proportion their FDI in a given host is partly driven by the desire to reduce the variable cost of transporting goods from home production facilitates.

While Japanese investors in textile, apparel and leather (ISIC-32), chemical products (ISIC-35) and basic metal (ISIC-37) industries are more likely to allocate larger proportion of their FDI to hosts with strong anti-corruption measures, Japanese investors in food and beverage, forest related products (ISIC-31 and ISIC-33) and others (ISIC-39) manufacturing industries appear to be very wary of the politically instability of the host nations. In general, results from both tables indicate that hosts with better infrastructure quality, good measures to combat corruption, and a larger domestic market (population size) appear to attract relatively larger proportion of Japanese FDI in food beverage and tobacco, and wood products and furniture industries. The proportion of Japanese FDI in textile apparel and leather, and basic metal industries that goes to a given host appears to be an increasing function of the size of labor in the primary sector. Our results also indicate that the effects of the cost of capital on the allocation of Japanese industry specific FDI across different host nations is generally very weak across all industries.

\section{Conclusion}

The amount and type of inward FDI that a nation receives is often a direct result 
of its market characteristics (resource abundance, infrastructure, institutions etc). Despite similarities between host markets in many of these characteristics, some host nations receive significantly larger amounts of inward FDI than other nations simply because they provide easy access to third-party markets. That is, they serve as gateways or export platforms for industries targeting other markets. As the host's export platform status is typically not taken into account, empirical observations on the FDI-trade interaction literature are largely inconclusive.

This paper takes into account the host market's export platform status and evaluates the Japanese industry specific FDI-export sales link for the period 1989-1998. Our results indicate that the FDI-export sales interaction is both industry specific and subject to the host's export platform status. In fact, after accounting for the hosts' export platform status, previous results on the FDI-export sales link change for several industries. For example, in ISIC-32 (textile, apparel, and leather) and ISIC33 (wood products and furniture), including the host' export platform status changes the relationship from that of substitutes to one of complements. We also observe changes in the effect of export sales on inward FDI from positive (complements) to negative (substitutes) in other industries. The changes in the sign and the marginal effects of the export sales variable when we account for the host's export platform status indicate that the exact nature of the FDI and export sales interaction is not only industry specific but also subject to the host's export platform status. Therefore, it is no surprise that earlier studies' results for which a host's export platform status is not accounted for are generally inconclusive in regard to the FDI-export sales link.

Finally, our study indicates that export platform nations receive proportionally larger amounts of FDI in food, beverage, and tobacco and chemical product industries than compared to host nations that attract Japanese FDI to service either their local markets and/or export back to the Japanese market. However, export platforms attract significantly lower proportion of FDI in several other industries, namely the textile, apparel, and tobacco industries, wood products and furniture, fabricated metal products, and miscellaneous manufacturing industries.

Although our analysis suggests the host's EP status plays an important role in the interaction between FDI and export sales, our conclusion should be taken with caution. First, we follow much of the previous literature on this topic by examining a linear relationship between FDI and export sales. Clearly, there may be a nonlinear dimension to this relationship. Second, the host's EP status was defined and considered constant for a set of years (1985-1998), and clearly an EP designation 
may change over time as the result of variations in host country trade, political, and other domestic policies. Lastly, we examined a host's EP status from the point of view of the overall Japanese manufacturing FDI. It may well be that not all industries view a particular host as an export platform. Thus, future research on the creation of a dynamic, industry-specific EP measure appears to be in order.

\section{Acknowledgement}

We would like to thank Matthew Higgins and Susan Pozo, Department Economics, Western Michigan University, for their consistent comments on earlier version of this papter.

Received 9 July 2004, Accepted 26 December 2004

\section{References}

Blonigen, B. (2001) In Search of Substitution Between Foreign Production and Exports, Journal of International Economics, 53, 81-104.

Blonigen, B. (2002) Tariff-jumping Antidumping Duties, Journal of International Economics, 57, 31-49.

Brainard, S.L. (1997) An Empirical Assessment of the Proximity Concentration Trade-off Between Multinational Sales and Trade, American Economic Review, 8, 520-544.

Dunning, J.H. (1988) The Eclectic Paradigm of International Production: a Restatement and Some Possible Extensions. Journal of International Business Studies and Statistics, 41, 269-295.

Egger, P. (2001) European Exports and Outward Foreign Direct Investment: A Dynamic Panel Data Approach, Welwirtschaftiliches Archiv, 137,427-449.

Ekholm, K., Forslid, R., Markusen, J. (2003) Export-platform Foreign Direct Investment, NBER Working Paper \#9517.

Gopinath, M., Pick, D., Vasavada, U. (1999) Exchange Rate Effects on the Relationship Between Fdi and Trade in the U.S. Food Processing Industry, American Journal of Agricultural Economics, 80, 1073-1079.

Hanson,G., Mataloni, R., and Slaughter, M. (2001) Expansion Strategies of U.S. Multinational firms, in Brookings Trade Forum (Ed.) Rodrik, D., Collins, S., pp. 245294.

Head, K., Mayer, T. (2004) Market Potential and the Location of Japanese Investment in Europe, Review of Economics and Statistics, 86, 959-972.

Hejazi, W., Safarian, A. (2001) The Complementarity Between U.S. FDI Stock and Trade. Atlantic Econ. Journal, 29, 420-437. 
Helpman, E., Melitz, M., Yeaple, S. (2004) Exports Versus FDI with Heterogeneous Firms. American Economic Review, 94, 300-316

Hsiao, C. (1986) Analysis of Panel Data, Econometric Society Monograph, Cambridge University Press, Cambridge (UK).

Jones, R. (2000) Globalization and the Theory of Input Trade, MIT Press, Cambridge.

Kaufmann, D., Kraay, A., Zoido-Lobaton, P. (1999) Aggregating Governance Indicators. World Bank Policy Research Working Paper No. 2195.

Marchant, M., Cornell, D., Koo, W. (2002) International Trade and Foreign Direct Investment: Substitutes or Complements? Journal of Agricultural and Applied Economics, 34, 289-302.

Markusen, J. (1990) First Mover Advantage, Blockaded Entry, and the Economics of Uneven Development. NBER Working Paper \#3284.

Markusen, J. (1995) Incorporating the Multinational Enterprise into the Theory of International Trade. Journal of Economic Perspectives, 9, 169-189.

Markusen, J. (2002) Multinational Firms and the Theory of International Trade, MIT Press, Cambridge (MA).

Markusen, J. Maskus, K. (2001) Multinational Firms, Reconciling Theory and Evidence?, in Topics in Empirical International Economics, A Festschrift in Honor of Robert E. Lipsey (Ed.) Blomstrom, M., Goldberg, L., University of Chicago Press, Chicago.

Markusen, J. and Maskus, K. (2002) Discriminating Among Alternative Theories of the Multinational Enterprise, Review of International Economics, 10, 694-707.

MIGA (2002) Foreign Direct Investment Survey. Washington, D.C., The World Bank Group.

Mody, A., Srinivasan, K. (1998) Japanese and U.S. Firms as Foreign Investors: Do They March to the Same Tune?, The Canadian Journal of Economics, 31, 778-799.

Mundell, R. (1957) International Trade and Factor Mobility, American Economic Review, 47, 321-335.

Pfaffermayr, M. (1996) Foreign Outward Direct Investment and Exports in Austrian Manufacturing: Substitutes or Complements?, Welwirtschaftiliches Archiv, 132, 501521.

Safarian, A. (1996) World Investment Report 1996: Investment, Trade and International Policy Arrangements, Transnational Corporations, 5, 163-173.

Stone, S., Jeon, B. (2000) Foreign Direct Investment and Trade in Asia-Pacific Region: Complementarity, Distance, and Regional Economic Integration, Journal of Economic Integration, 15, 460-485.

Tadesse, B., Ryan, M. (2004) Host Market Characteristics, FDI, and the FDI-Trade Relationship, Journal of International Trade and Economic Development, 13, 197227.

United Nations Center for Trade and Development (UNCTAD) (1996): World Investment Report: Investment Trade and International Policy Arrangements, Geneva and New York, United Nations Publications.

United Nations Center for Trade and Development (UNCTAD) (2001), World Investment 
Report: Promoting Linkages, Geneva and New York, United Nations Publications. Waldkirch, A. (2003) The 'New Regionalism' and Foreign Direct Investment: The Case of Mexico, Journal of International Trade and Economic Development, 12, 151-184. Wheeler, D. and Mody, A. (1991) International Investment Location Decisions: The Case of U.S. Firms, Journal of International Economics, 33, 57-76.

Yilmaz, A. (2001) Essay on Foreign Direct Investment (FDI) and Trade, unpublished $\mathrm{Ph} . \mathrm{D}$ dissertation, University of California, Davis. 


\section{Appendix}

A. The Dependent Variable $\left(\boldsymbol{Y}_{i t}^{(j)}\right)$ : to create our dependent variable, first we collect, $C_{i j t}$, the total value of ISIC-2 digit level (industry j) Japanese FDI invested in each hosts (i), during a given year ( $\mathrm{t}$ ). Considering the study period (199891998), the 35 Japanese FDI host countries in our sample, and the seven industry types, $\sum_{i=1}^{35} \sum_{j=1}^{7} \sum_{t=1989}^{1998} C_{i j t}$ measures the total value of Japanese manufacturing FDI invested in the host countries considered in this study. We compute our dependent variable as $\left(\frac{C_{i j t}}{\sum_{i=1}^{35} \sum_{i=1}^{7} \sum_{t=1989}^{1998} C_{i j t}}\right) \times 100$.

Thus our dependent variable $\left(Y_{i t}^{(j)}\right)$ measures the industry specific proportion of Japanese manufacturing FDI received in host country $i$, during a given year $t$. It captures both the cross sectional and time variation of industry specific manufacturing FDI received by each host.

B. List of Host Countries: EU-15 (Austria*, Belgium* ${ }^{*}$, Denmark ${ }^{*}$, Finland*, France, Germany, Greece ${ }^{*}$, Ireland ${ }^{*}$, Italy, Luxembourg ${ }^{*}$, Netherlands ${ }^{*}$, Portugal*, Spain*, Sweden, UK); plus Argentina*, Australia, Brazil", Canada, China, Hong Kong, Hungary*, Iceland*, India, Indonesia, Korea, Mexico*, New Zealand, Norway, Philippines, Poland, Singapore, Taiwan, Thailand, Turkey, US.

Note: * indicates export platform countries. All other countries are either those in which production by Japanese firms located there is mainly consumed in the local host market itself (e.g. USA, UK) or re-exported to the FDI source (Japanese) market (e.g. Hong Kong, Taiwan).

\section{Data Sources and Description:}

- The selection of the reference years (1989-1999) is based on the availability of Japanese FDI and trade data as well as the availability of host-country specific data. Hosts were included in the sample if complete information for at least seven of the 11 years reference time was available. All currency-denominated variables with the exception of Japanese FDI values are measured in 1995 US\$. Japanese 
FDI values are expressed in 100 million $¥$.

- Data on outward Japanese FDI counts and values are from The Ministry of Finance of the Government of Japan's web page at: http://www.mof.go.jp/ english/files.htm. The FDI data covers only direct private investment. Official Japanese government investments and overseas direct aid are not included. Despite the presence of censored information when the data is disaggregated into sectors or industries, we believe that the data are representative and accurate.

- Japanese trade data is from OECD Commodity Trade statistics CD ROM 2000 Version 5.2.

- Manufacturing imports/exports provided by the World Bank. Data is converted to 1995 USD. (http://www1.worldbank.org/wbiep/trade/TradeandProduction)

- Exchange rate data is from the IMF's International Financial Statistics. Market rates, when available, are used to convert host currencies to Japanese Yen. Annual exchange rate volatility is computed by taking the log difference of the monthly exchange rate and averaging it over 12 months period.

- Tariff rate data are based on un-weighted averages for all goods. Ad valorem rates, applied rates, or MFN rates whichever data are available in a longer period. Data are from WTO, IDB CD-ROM database and Trade Policy Review -Country Report, Various issues, 1990-2000; UNCTAD, Handbook of Trade Control Measures of Developing Countries -- Supplement, 1987 and "Directory of Import Regimes, 1994; World Bank, Trade Policy Reform in Developing Countries since 1985, WB Discussion Paper \#267, 1994, The Uruguay Round: Statistics on Tariffs Concessions", and "Given and Received, 1996 and World Development Indicators, 1998-00; OECD, Indicators of Tariff and Non-Tariff Trade Barriers, 1996; IDB, Statistics and Quantitative Analysis data, 1998”.

- Data on labor force by the production sector, land area $\left(\mathrm{km}^{2}\right)$, infrastructure (Total road network (km)), population (in 1000s), GDP (in Millions of 1995 US\$) are all from World Development Indicator (2001) CD-ROM.

- Lending rate data is from the IMF's International Financial Statistics. In cases where information on lending rates is not available for a given year, the missing rate was replaced by a mean of the available lending rates prior to the year in which the data is missing. 